\title{
ELIA
}

Estudios de Lingüística Inglesa Aplicada

\section{IMMIGRANT LEARNERS' CULTURAL IDENTITIES IN THE VOCABULARY INPUT OF EFL TEXTBOOKS THROUGH PROTOTYPICAL ASSOCIATIONS}

\section{IDENTIDADES CULTURALES DE ESTUDIANTES INMIGRANTES EN EL VOCABULARIO DE LIBROS DE TEXTO DE INGLÉS A TRAVÉS DE ASOCIACIONES PROTOTÍPICAS}

\section{María Daniela Gifone Ponte \\ University of La Rioja, Spain \\ $\underline{\text { m-daniela.cifone@unirioja.es }}$}

\section{Jaqueline Mora Guarín \\ University of La Rioja, Spain \\ jaqueline.mora@alum.unirioja.es}

\section{Abstract}

In recent decades, scholars' attention has been focused on how the target and source cultures can be integrated to EFL materials. Despite significant progress in this respect, the source culture is still considered as the predominant culture in a classroom, even in countries where immigration is reaching unprecedented numbers (Suárez Orozco, 2001; McKay, 2003). This poses some challenges for selecting the vocabulary input for EFL materials and promoting cultural diversity in the classroom. For this reason, since semantic prototypes are anchored in the categorisation of mental lexicon (Taylor, 1989; Aitchison, 2003), they may shed light on what cultural words are being and should be integrated to EFL textbooks to foster 
the integration and balance of predominant and non-predominant cultures. This study aims to examine whether immigrant learners' cultures are evidenced in the vocabulary input of two EFL textbooks used in La Rioja, Spain; and to analyse if these cultural identities are represented through prototypical associations by means of two semantic categories: free-time activities and festivities. The results suggest that (i) the target culture is pervasive while immigrant students' cultures are scarcely included in EFL materials; (ii) there are similarities and differences regarding the cultural aspects drawn through prototypical associations in the two EFL textbooks selected; and (iii) the cultural identity aspects are scarce because most of the vocabulary input of EFL textbooks is focused on the use of words from the target language. The present study has implications for textbooks publishers and multilingual learners as it provides insights into the unbalanced cultural picture that EFL textbooks draw through word associations.

Keywords: cultural vocabulary, Immigrant EFL learners, EFL textbooks, Prototypical associations, Multilingualism.

\section{Resumen}

En las últimas décadas, la integración de las culturas meta y origen en los libros de texto de inglés como lengua extranjera (ILE) ha recibido enorme atención académica. Sin embargo, a pesar de que se han conseguido muchos avances en este respecto, la cultura origen del alumno sigue siendo aquella que es más predominante en el aula, incluso en aquellos países donde la inmigración ha alcanzado cifras sin precedentes (Suarez Orozco, 2001; McKay, 2003). Esto plantea algunos desafíos a la hora de seleccionar el vocabulario de los libros de texto y promover la diversidad en el 
aula. Por esta razón, dado que los prototipos semánticos están centrados en la categorización del léxico mental (Taylor, 1989; Aitchison, 2003), pueden arrojar luz sobre qué palabras culturales se están incluyendo y cuáles deberían de ser integradas en sus contenidos para promover la integración y el equilibrio cultural. Este estudio tiene como objetivo examinar si las culturas de los estudiantes inmigrantes se evidencian en la enseñanza de vocabulario de dos libros de texto de ILE utilizados en La Rioja, España, y analizar si estas identidades culturales se representan a través de asociaciones prototípicas mediante dos categorías semánticas: actividades de tiempo libre y festividades. Los resultados sugieren que: (i) la cultura meta es dominante, mientras que las culturas de los estudiantes inmigrantes apenas se incluyen en los materiales; (ii) hay similitudes y diferencias con respecto a los aspectos culturales extraídos a través de asociaciones prototípicas en los dos libros de texto seleccionados; y (iii) los aspectos de identidad cultural son escasos debido a que la mayor parte del vocabulario de los libros de texto de ILE se centra en la cultura meta. Este trabajo tiene implicaciones para las editoriales y los estudiantes multilingües, ya que proporciona información sobre el desequilibrio cultural que se evidencia en los libros de ILE a través de asociaciones de palabras prototípicas.

Palabras clave: vocabulario cultural, aprendices inmigrantes, libros de texto de ILE, asociaciones prototípicas, multilingüismo.

\section{Introduction}

Beyond the concept of culture as a set of attitudes and behaviours, culture and language are intertwined, one cannot exist without the other (Cifone Ponte, 2019). That is, learning a non-native language 
along with its culture may raise awareness of students' own culture while promoting a sense of belonging (Nizegorodcew, 2011). In the context of English as a foreign language (EFL), culture is gaining ground in European policies since intercultural competence is currently at the core of the Common European Framework of Reference for Languages (henceforth, CEFR) (Council of Europe, 2001). This is creating the need of integrating culture not only in language instruction but also in language teaching materials. For this reason, scholars' attention has been focused on how the target and source culture can be included in EFL textbooks to facilitate intercultural and multicultural communication (Xiang \& YenikaAgbaw, 2019). Traditionally, English instruction has been addressed from a monocultural perspective (Alptekin, 1993; Halverson, 1985). This assumption created an ethnocentric conception of English which soon became unreal and limited as globalization spread. Nowadays, the predominant status of the target culture, especially those cultures belonging to the inner circle, is still undeniable. However, in contrast to this traditional approach, a large body of literature is defining and prioritizing the role of the students' own language and the source culture in foreign language learning (McKay, 2003; Duñabeitia, 2017). Amidst these changes, the source culture is still considered to be the predominant culture in the classroom, even in countries where different cultures coexist in the classroom (Suárez Orozco, 2001).

The question of what culture to include and how it should be addressed is challenging the selection of the vocabulary input in EFL materials globally. Since vocabulary conveys cultural meanings and subtleties (Wierzbicka, 1992), cultural words should be selected carefully to foster diversity and multiculturalism in the classroom. Research on the words associated in response to semantic categories 
is essential for not only understanding how bilingual and monolingual EFL learners categorise vocabulary (Pavlenko, 2009), but also analysing how culture may affect the categorisation of mental lexicon. Culture and prototypes have been studied separately and have received scant scholarly attention. Although cultural psychologists argue that the influence of culture on micro-level cognitive processes such as categorisation (Ji, Nisbett \& Zhang, 2004), nothing has been published in linguistic circles regarding culture and prototypes in EFL.

This study seeks to examine the convergence of culture and semantic prototypes to determine whether the cultural identity of immigrant learners is evidenced in the vocabulary input of EFL textbooks. A selection of words from two semantic categories festivities and free-time activities - will be examined employing a content analysis of two of the EFL textbooks most frequently used in the sixth year of primary education in the Autonomous Community of La Rioja, in northern Spain. This study thus broadens new perspectives concerning EFL teaching and learning in two ways: (i) it seeks to define whether EFL materials for young learners acknowledge the existence of diverse source cultures in one classroom by integrating immigrant cultures in their vocabulary input; and (ii) it analyses prototypical associations in cultural semantic categories to ascertain whether cultural identities are evidenced.

The study is organised into four sections. The first section briefly reviews intercultural competence, semantic prototypes, and conceptualizations of culture as well as the related studies on this matter. The second section describes the sample and the data management of our study. Subsequently, in the third section, we will 
present the results obtained from the analysis of cultural words observed in the materials and the discussion of the data with the main literature. In the fourth section, we will unveil our conclusions and its implications for further studies on vocabulary acquisition in EFL.

\section{Review of literature}

\subsection{Globalization, cultures, and language teaching}

The notion of culture has a remarkable role in the process of communication in multicultural contexts (Liddicoat \& Scarino, 2013). According to Liddicoat and Scarino (2013), globalization along with an increased mobility may have reshaped the way we live and communicate and is increasing the need of developing and integrating intercultural skills in foreign language teaching and learning. Within this context, it is vital to bear in mind that the process of becoming proficient in a foreign language is complex and that it will always imply exposure to cultural aspects and new word associations. These new associations "reflect a multifaceted reality, implied meanings and symbols" which are key in the process of understanding and communicating (Nizegorodcew, 2011, p. 9). In other words, being culturally aware implies accepting different assumptions and practices from other cultures, an attitude that facilitates communication. Therefore, culturally aware students may dominate more linguistic and cultural subtleties in speech than students lacking in that awareness (Halverson, 1985).

In recent decades, Europe has witnessed massive migratory movements within its borders (Hoskins \& Sallah, 2011). Hoskins and Sallah (2011) argue that the importance and the effect of this cultural diversity on the host countries depends on the acceptance of these groups by the dominant majority. Within this acceptance lies the 
concepts of "culture, the colour of the skin, perception of wealth of the individual and perception of threat to local employment" (Hoskins \& Sallah, 2011, p. 114). Hence, European policies concerning education and culture include the intercultural competence as necessary to fostering intercultural dialogue (Culture Council, 2008; Hoskins \& Sallah, 2011). Moreover, being an interculturally competent person implies having a deeper knowledge of one's own culture. In fact, in their model of intercultural competence, King and Baxter Magolda (2005) describe intercultural competent learners as speakers who have a great sense of identity; explore their own cultures and values; are immersed in their own culture; and are proud of it.

For these reasons, culture has gained a relevant status within the context of foreign language teaching and learning in recent years (Liddicoat \& Scarino, 2013). Notwithstanding the complexity of the concept within the EFL field, the most recurrent definition describes culture as the specific features of a national group that can be limited by geographic borders (Liddicoat \& Scarino, 2013). Nevertheless, such a view reduces culture to a set of describable and fixed national attributes which may contribute to the creation of stereotypes and exclude ethnic minorities and different social classes (Liddicoat \& Scarino, 2013). This view has been predominant in foreign language instruction and teaching materials in which culture - more specifically, the target culture - is described as a defined and strict set of values, attitudes and costumes through cultural notes and images of popular cultural attributes (Holliday, 2010).

However, in his model of intercultural competence, Byram (1997) argues that knowledge (savoirs) about cultures, society and the individuals are vital in this process, yet he adds to this knowledge a 
set of skills and attitudes which promote an attitude of curiosity and openness. Furthermore, Liddicoat and Scarino (2013) clarify that culture should not be treated as a body of knowledge but as a whole framework where "people live their lives, communicate, and interpret shared meanings" (2013, p. 22). In this vein, Norton (2000) acknowledges culture as a changing concept which may be affected and modified by factors such as time, place, age, gender, among others. Within this paradigm, some scholars notice that the concept of culture, as dynamic as it is, posits some problems for EFL (Hoskins \& Sallah, 2011).

It seems essential, then, to distinguish between cultural and intercultural perspectives. Liddicoat and Scarino (2013) defined a cultural perspective as that approach focused on one culture which is normally external and foreign for the learner, whereas an intercultural perspective seeks the integration of learners' own culture during the process of learning a language. This last approach should be followed by textbooks, since integrating cultures into these materials fosters intercultural competence in the classroom.

Another basic distinction germane to our study is the classification of cultures attending to the source and the target languages (Risager, 1991; Byram, 1997). On the one hand, "target culture" refers to the culture or cultures involved in the study of a language; in the case of EFL, the cultures of those countries where English is the official language. According to Kachru's model of World Englishes as reference, these countries would be the ones from the inner circle (e.g., USA, UK, Canada) (Kachru, 1985). On the other hand, "source culture" refers to the students' native culture. In the late 90s, this dichotomy was interrupted by the term "international culture". Within the field of EFL, this type of culture differs from the 
students' and the target culture (Cortazzi \& Jin, 1999). For instance, in the case of EFL teaching in Spain, Asian cultures could be considered international cultures.

\subsection{The role of culture in EFL materials}

Teaching materials or to be more accurate, textbooks are one of the main sources of cultural information in the classroom (ClavelArroitia \& Fuster-Márquez, 2014; Bahrami 2015). Accordingly, educators rely on them to introduce cultural aspects in a controlled and non-stereotyped way (Liddicoat \& Scarino, 2013). In the European Union, EFL materials used in formal education are designed to meet the specifications of the CEFR (Council of Europe, 2001). This official document includes intercultural competence as an essential part of any language curricula. Moreover, in Spain, language programs' syllabi must adhere to not only the CEFR's requirements, but also current education law and the different Autonomous Communities' decrees which establish the curricula of formal education.

Recent research on the inclusion of cultures in EFL teaching materials has led scholars to delve into which culture should predominate in foreign language instruction. Globalization has affected EFL textbooks' cultural scope to the extent of 'denationalizing' their content (McKay, 2003). To be more precise, a large body of literature supports this idea and points out to the extended predominance of the target culture in these materials and in teaching practices (Sercu, Méndez García \& Castro Prieto, 2004; Wu, 2010; Yuen, 2011; Gómez Rodríguez, 2015; Cifone Ponte, 2019; Ayu, 2020). Regarding teaching, investigations on the common practices in the EFL classroom point out that topics concerning the target culture's daily life, routines and festivities are the most 
addressed topics in the EFL classrooms (Harvey, Roskvist, Corder \& Stacey, 2011; Sercu, Méndez García \& Castro Prieto, 2004). In the same vein, EFL materials tend to focus primarily on British and American cultures (Lee, 2009; Abdollahzadeh \& Baniasad, 2010; Canga Alonso \& Cifone Ponte, 2015). Nevertheless, the studies cited above were conducted with a sample of textbooks used in secondary education or addressed to adult learners. Although little has been published on cultural perspectives in Primary Education EFL textbooks, some studies reported a change of trend. For instance, Joo, Chik and Djonoy (2019) focused on the images of five EFL textbooks used in primary school in Korea. Interestingly, their main findings showed that most of the materials have been adapted to the Korean curriculum requirement of representing English as a global language by including characters from a wide range of cultures. However, there is need for further research as these findings may not be extrapolated to other EFL contexts.

In contrast, Méndez García (2005) believes in the necessity of the inclusion of the target culture as it is crucial for the students to be exposed to some characteristics and behaviours of the target society. What is more, she claims that glimpses from the target culture in EFL textbooks may develop students' ability of reflection and respect (Méndez García, 2005). Nevertheless, other scholars claim that the source culture should be the most relevant in EFL materials. For example, McKay (2004) proposes designing local textbooks that emphasise the view of local authors and local cultures. This proposal is supported by evidence which accords great benefits to the inclusion of the source culture in the instruction of a foreign language (Nault, 2006; Duñabeitia, 2017). Despite this sustaining evidence, numerous studies emphasise the lack of attention of the students' culture in EFL 
materials (Böcü \& Razi, 2016; Chao, 2011; Canga Alonso \& Cifone Ponte, 2015).

In this regard, the CEFR determines that learners should be capable of relating the target and source culture as a tool to cope with interculturality, and that EFL teachers and textbooks should foster a learning environment where students can develop strategies to communicate with people from other cultures without misunderstandings and judgements (Council of Europe, 2001). However, the inclusion of the source culture is not fully linked to the country where the textbook is going to be used, as immigrants or firstgeneration immigrants may not consider the predominant culture as theirs. This poses some problems when it comes to deciding which culture should receive more attention in EFL instruction. Some scholars stress the need of a balance in the representation of not only the source and the target cultures but also international cultures (Cifone Ponte, 2019; Mendez García, 2005). This practice may be a way of integrating the target culture, which will be essential for communication, and the diverse source cultures that may coexist in the EFL classroom.

\subsection{The theory of prototype and its evolution}

The interpretation of the Aristotelian classical theory of categorisation changes considerably in Rosch's (1975) prototype conception. This scholar suggests that a prototype is the best, central, and most representative exemplar in a category. Besides, these categorical members are arranged in order of "goodness," that is, similar things to the prototype are classified as very typical or good members and dissimilar things as being less typical or less good members (Murphy, 2002). In some of Rosch's studies (1975; Rosch et 
al. 1976; Rosch \& Lloyd, 1978), for instance, the central case in the category fruit is apple, whereas the least representative member is olive. In our view, this theory implies that the prototype is the exemplary best recognized by the human being in a category. Dubois $(1981,1983)$ revealed that the prototype is the best exemplar when it is the most frequently used item instead of being the central case of the category solely.

The evolution of the concept of prototype broadens its significance and implication in categorisation under different models (cf. Wittgenstein, 1953; Fillmore, 1975; Rosch \& Mervis, 1975; Tversky, 1976; Coleman \& Kay, 1981; Cordier \& Dubois, 1981; Jackendoff, 1983; Schwarze, 1985; Lakoff, 1986, 1987; Geeraerts, 1987; Langacker, 1987; Rosch, 1976, 1978; Wierzbicka, 1992; Kleiber, 1995). This development of the definition of "prototype" and its theory is explored in two different versions: The standard version and the extended version. In both versions, the prototype becomes the central case in the category. The standard version proposes that the prototype not only is the central member of a category but also it is organised through different levels of categorisation (Superordinate, Basic and Subordinate). In this hierarchy, the basic level is the most salient, learned first by children and easily identified (Kleiber, 1995). However, as conceptualized in Lakoff's (1987) extended version, not all the categorisation cases can be prototypical. The prototype becomes the element in which the category is organised regarding membership gradience. This membership refers to multiple cognitive tasks, which from a monosemic conception becomes a polysemic relationship, as the family resemblance theory suggests (Wittgenstein, 1953). In other words, the members of a category might be linked without the existence of a common feature among 
all members. Both standard and extended versions have contributed to understanding the role of prototypes in studies on linguistic and semantic categories.

\subsection{Semantic prototypes and cultural conceptualizations}

Recent work on prototypes to analyse semantic categories have been used in terms of cultural conceptualizations such as event schema, which refers to the description of the semantic category and the words associated with it (Sharifian, 2003). Furthermore, van Vliet's (2019) prototype approach describes how cultural festivities are seen as natural categories. For instance, festivals can be described based on certain characteristics, but they cannot be defined within a single set of necessary and sufficient characteristics. Therefore, a celebration like Christmas might share similar characteristics worldwide (e.g., family dinner, exchange of presents). However, what makes Christmas unique in terms of culture varies according to one's traditions, costumes, and religion. Likewise, Lakoffs (1997) theory on radial cultural categories as free-time activities will describe how the prototype is evidenced by means of the family resemblance theory. This theory emphasises the idea of membership in a category despite having non- shared features (see Wittgenstein, 1953).

As for studies regarding cultural identity in the vocabulary input of EFL textbooks through prototypical associations, little research has been produced. However, concerning prototypes, a growing body of literature has examined L1 and L2 studies. These revisions have focused on the most typical characteristics of a category, namely lexical availability, word associations, word order, family resemblance, prototypical levels, fuzzy sets, cross-cultural 
prototypes, prototypes identity, and linguistic components such as grammar, morphology, syntax, phonology and vocabulary.

Concerning vocabulary research in EFL settings, there have been analysis of adjectives in the prototypicality of word senses (Yuan, 1990; Lukusa, 1996); the frequency of input of words through prototype networks has been explored (Vermeer, 2001); English prepositions and the prototypical sense provided in the acquisition of an L2 (Cho, 2010); the basic- level salience through the recognition of prototype levels of categorisation (Xia \& Georg- Wolf, 2010); vocabulary acquisition and teaching by means of using learning and teaching prototype models (Duan \& Da, 2015); and vocabulary acquisition seen from the perspectives of culture and psycholinguistic aspects such as lexical availability (Carcedo, 1998; Šifrar Kalan, 2017) and word associations (Mora Guarín \& Jiménez Catalán, 2019) to recognize either universality of language or divergences or convergences in the field of semantic prototypes through the use of two semantic categories. Nevertheless, studies on cultural identities in the vocabulary input of EFL textbooks employing prototypical associations have not been published. In our research, we only found one study conducted by Yuen (2000) about the pedagogical implications of prototype theory in the writing of English grammar textbooks. Following Yuen, we strongly agree with two ideas: (i) textbooks are significant learning tools; and (ii) as suggested by Lakoff, (1987, cited in Yuen, 2000), our cognitive system depends on our physical and cultural experience. To the best of our knowledge, ours is the first attempt to investigate how the immigrant learners' cultural vocabulary of two semantic categories in two different EFL textbooks used in primary school will be evidenced through semantic prototypes. The research questions are as follows: 
1. Are cultural words concerned with the semantic categories of festivities and free-time activities included in the vocabulary input of $6^{\text {th }}$ year of primary education EFL textbooks?

2. What are the prototypical associations that emerge from this vocabulary? Are immigrant learners' cultures (i.e., Romanian, Chinese, Moroccan, Colombian, Bolivian and Ecuadorian) represented or, the vocabulary input is mostly dominated by references to the target culture?

\section{Methodology}

\subsection{Sample}

As mentioned in the introduction, this study will focus on the vocabulary input in two EFL textbooks commonly used in La Rioja, an Autonomous Community in the north of Spain. More specifically, the sample comprises two of the most frequently used textbooks for Sixth grade in the Autonomous Community of La Rioja: Big Surprise and Mission Accomplished.

In this region, $12,8 \%$ of students between 6 and 11 are immigrants (Ayuntamiento de Logroño, 2018). In order to define whether immigrant learners' cultures are evidenced in the vocabulary content, the four main immigrant students' nationalities in La Rioja were considered: Rumanian, Chinese, Moroccan, Colombian, Bolivian and Ecuadorian (Ayuntamiento de Logroño, 2018).

\subsection{Data analysis and management}

The data presented in this paper were analysed by applying a content analysis. This allowed our qualitative data to be examined systematically and reliably so that generalizations could be made from them in relation to the categories of our interest. In our case, the 
analysis of the two textbooks was conceptual. The object of analysis were words (e.g., crackers), and lexical units of meaning (e.g., eggs rolling competition) from all the written content of the materials (i.e., grammar and vocabulary exercises, cultural sections, reading activities and texts). This method allowed us to identify present important aspects of the vocabulary content of the two textbooks regarding valuable cultural insights of immigrant L1 learners through prototypical associations.

Both - the curriculum of La Rioja (Decree 24/2014) and the CEFR (Council of Europe, 2001) - were used to define two cultural categories which are representative in materials at this educational level. The curriculum of La Rioja (Decree 24/2014) establishes that young learners at this stage should be aware of customs and traditions from the target culture as well as celebrations such as "Halloween, Valentine's Day, Christmas, Saint Patrick, Pancake Day, Easter” among others (Decree 24/2014, p. 1382). What is more, students should be instructed in vocabulary related to free-time activities and hobbies (Decree 24/2014). Both topics are also described within the list of cultural topics offered by the CEFR (Council of Europe, 2001). Customs and traditions are descriptors found in the categories of Ritual behaviours and Values, beliefs and attitudes (Council of Europe, 2001, pp. 102-103). Likewise, free-time activities and hobbies are included as descriptors of the cultural category Everyday living (Council of Europe, 2001, pp. 102-103).

Regarding the prototypes analysis, we have adopted the following methodological decisions. In order to define the type of category, we relied on Lakoff's representation of radial categories (1987), Sharifian's cultural conceptualizations and van Vliet's prototype approach (2019). As explained in the literature review, the 
category of free-time activities has been previously defined as radial (Lakoff, 1987 cited in Hernandez Muñoz, 2006).

With reference to festivities, we considered cultural celebrations as a natural and specific category, which cannot be described within a single set of necessary and sufficient characteristics (van Vliet, 2019). Apart from that, this semantic category was also examined using Sharifian's (2003) event schema. According to this author, schemas describe people's experience of certain events which are shared and experienced similarly by people from the same cultural background. Each culture has schemas for important events and festivities (e.g., weddings or funerals) and each schema encompasses sub-schemas about the events (e.g., church ceremony). In our study, words referring to festivities were extracted and were treated as schemas (e.g., Christmas), while those words describing the event were treated as categories associated with the schema (e.g., crackers).

Data management and analysis were performed using Microsoft Excel. Since we classified cultural words by textbook and category, we obtained four lists. The prototypes extracted from the cultural words were classified regarding the three types of culture (i.e., target, source and international) paying special attention to those predominant immigrant's culture in La Rioja (Rumanian, Chinese, Moroccan, Colombian, Bolivian and Ecuadorian). Any reference to these cultures and the Spanish culture, which is the predominant culture in the Autonomous Community, will be considered as the source culture.

\section{Results and Discussion}

The first research question aimed to determine whether cultural words related to the categories of festivities and free-time activities 
were included in the vocabulary input of the textbooks. Our data revealed that both categories were present in the content of the materials. However, in terms of quantity, the two textbooks reported a higher presence of terms related to celebrations (see table 1 and 2). As expected, this finding shows EFL textbooks used in sixth year of primary education in La Rioja foster cultural aspects related to both festivities and everyday life activities as established in the curriculum of this Autonomous Community (Decree 24/2014) and the CEFR (Council of Europe, 2001). Our data also corroborate the findings of previous studies which pointed to festivities and folklore and daily routines as a pillar of culture teaching in the EFL classroom (Harvey, Roskvist, Corder \& Stacey, 2011). Unlike Secondary Education EFL materials where there is greater inclusion of everyday cultural aspects such as hobbies (Dehbozorgi, Amalsaleh \& Kafipour, 2014; Cifone Ponte, 2019), our data seems to point to a tendency to introduce culture through festivities in textbooks designed for primary education. These findings agreed with Kirkgöz and Agcam's (2011) whose study revealed festivities were among the most represented cultural topics in young learners' textbooks.

\begin{tabular}{|l|l|l|}
\hline Textbook & Cultural words & Prototypes \\
\hline \hline $\begin{array}{l}\text { Big } \\
\text { Surprise }\end{array}$ & $\begin{array}{l}\text { Bonfire night, making a guy, } \\
\text { putting guys on the bonfire, } \\
\text { fireworks, firework display, } \\
\text { sparklers, rockets, toffee apples; }\end{array}$ & $\begin{array}{l}\text { Bonfire night (target } \\
\text { culture, British) }\end{array}$ \\
\hline & $\begin{array}{l}\text { Christmas, Christmas stockings, } \\
\text { crackers, paper hats, figgy } \\
\text { pudding, Christmas pudding, } \\
\text { advent calendar, mince pies, } \\
\text { Christmas tree, Christmas cake, }\end{array}$ & $\begin{array}{l}\text { Christmas (target } \\
\text { culture, British) }\end{array}$ \\
\hline
\end{tabular}




\begin{tabular}{|c|c|c|}
\hline & $\begin{array}{l}\text { Christmas cards, buying and } \\
\text { wrapping presents, Christmas } \\
\text { decorations, New Year, } \\
\text { Christmas eve; Christmas dinner } \\
\text { sprouts, turkey, roast potatoes; }\end{array}$ & \\
\hline & $\begin{array}{l}\text { St Valentine's Day: Giving } \\
\text { flowers, Valentine cards, } \\
\text { Valentine presents, Valentine } \\
\text { poems; }\end{array}$ & $\begin{array}{l}\text { St. Valentine’s Day } \\
\text { (target culture) }\end{array}$ \\
\hline & $\begin{array}{l}\text { Easter, Giving Easter eggs, } \\
\text { Easter eggs, going egg rolling, } \\
\text { going to church, hunting eggs, } \\
\text { making Easter bonnets, hot cross } \\
\text { buns, good Friday, Easter } \\
\text { Saturday, Easter Sunday, Easter } \\
\text { Monday, Easter cards, chocolate } \\
\text { eggs, decorating eggs, Easter } \\
\text { parade, Eggs rolling } \\
\text { competition, rolling decorated } \\
\text { eggs, buying Easter eggs, parade, } \\
\text { Easter holidays, Easter } \\
\text { celebrations; }\end{array}$ & $\begin{array}{l}\text { Easter (target culture, } \\
\text { British) }\end{array}$ \\
\hline \multirow[t]{2}{*}{$\begin{array}{l}\text { Mission } \\
\text { Accom- } \\
\text { plished }\end{array}$} & $\begin{array}{l}\text { Columbus Day, Columbus, } \\
\text { native Americans, Latin } \\
\text { American, New World; }\end{array}$ & $\begin{array}{l}\text { Columbus Day (source } \\
\text { and target, Latin } \\
\text { American and } \\
\text { American and } \\
\text { Canadian) }\end{array}$ \\
\hline & $\begin{array}{l}\text { Thanksgiving, Black Friday, } \\
\text { Christmas shopping; }\end{array}$ & $\begin{array}{l}\text { Christmas shopping } \\
\text { (Target culture, } \\
\text { American and } \\
\text { Canadian) }\end{array}$ \\
\hline
\end{tabular}


Immigrant Learners' Cultural Identities in the Vocabulary Input of... .

\begin{tabular}{|l|l|l|}
\hline & $\begin{array}{l}\text { Martin Luther King's Day, } \\
\text { donating free time, helping the } \\
\text { poor, volunteering, holiday; }\end{array}$ & $\begin{array}{l}\text { Martin Luther King's } \\
\text { Day (target culture, } \\
\text { American and } \\
\text { Canadian) }\end{array}$ \\
\hline $\begin{array}{l}\text { Day of Reconciliation, South } \\
\text { Africa, public holiday. }\end{array}$ & $\begin{array}{l}\text { Day of Reconciliation } \\
\text { (international culture, } \\
\text { South African) }\end{array}$ \\
\hline
\end{tabular}

Although the category of festivities was present in both textbooks, the approach adopted was different in each. As shown in table 1, in Big Surprise, festivities was dominated by celebrations or event-schemas which, per se, are part of international cultures (e.g., Christmas, Easter). As mentioned above, Sharifian (2003) refers to these schemas as events experienced similarly by people from the same cultural background. However, our data indicate a high number of sub-schemas describing the main cultural event. For example, the event-schema Christmas is described in detail by sub-schemas such as crackers, paper hats and figgy pudding. These descriptors allowed us to claim that event-schemas in Big Surprise are dominated by the target culture, to be more thorough, by the British culture. On the contrary, Mission Accomplished reported fewer sub-schemas but celebrations commonly celebrated in specific countries such as Martin Luther King's Day in the United States and Canada. Furthermore, this book contained schemas and sub-schemas which refer to international cultures or the students' cultures (e.g., Columbus Day). In this regard, cultural words describing a particular celebration were more predominant in Big Surprise than in Mission Accomplished. Since both textbooks are addressed to young learners who may be at the first level of intercultural maturity (King \& Baxter 
Magolda, 2005), their cultural understanding is still rigid and stark cultural differences (as may be the case of brand-new celebrations) may cause resistance and a judgmental attitude. In our view, subschemas may be of greater importance at this stage as they enhance comprehension of cultural events which, on the surface, may be recognized as similar by learners from other cultures (Sharifian, 2003). Moreover, these descriptors provide the student with a broader view of these celebrations along with an extensive vocabulary to encode new conceptualizations (e.g., traditional food, decorations, practices) (Sharifian, 2003).

\begin{tabular}{|l|l|l|}
\hline Textbook & Cultural words & Prototypes \\
\hline $\begin{array}{l}\text { Big } \\
\text { Surprise }\end{array}$ & Manga & $\begin{array}{l}\text { Manga (international, } \\
\text { Japanese) }\end{array}$ \\
\hline & Teatime & $\begin{array}{l}\text { Teatime (target culture, } \\
\text { British) }\end{array}$ \\
\hline & $\begin{array}{l}\text { Rising a camel } \\
\text { listening Ireland tholidaditional } \\
\text { bagpipes, listening to Irish } \\
\text { songs, watching Irish dancing, } \\
\text { staying in a B\&B }\end{array}$ & $\begin{array}{l}\text { Riding a camel } \\
\text { (international/source, } \\
\text { Arab culture) }\end{array}$ \\
\hline & $\begin{array}{l}\text { Going to the beach, donkey } \\
\text { ride, funfair ride }\end{array}$ & $\begin{array}{l}\text { Going to the beach } \\
\text { (target, British) }\end{array}$ \\
\hline & Playing in the school orchestra & $\begin{array}{l}\text { Playing in the school } \\
\text { orchestra (international/ } \\
\text { target) }\end{array}$ \\
\hline $\begin{array}{l}\text { Mission } \\
\text { Accom- } \\
\text { plished }\end{array}$ & Rugby & $\begin{array}{l}\text { Rugby (target, } \\
\text { American/British) }\end{array}$ \\
\hline
\end{tabular}


Immigrant Learners' Cultural Identities in the Vocabulary Input of. . .

\begin{tabular}{|l|l|l|}
\hline & Playing hockey, ice-hockey & $\begin{array}{l}\text { Hockey (target, } \\
\text { Canadian) }\end{array}$ \\
\hline & $\begin{array}{l}\text { Going to an American } \\
\text { shopping centre }\end{array}$ & $\begin{array}{l}\text { American shopping } \\
\text { centre (target, } \\
\text { American) }\end{array}$ \\
\hline
\end{tabular}

Table 2 shows the cultural words concerning free-time activities. Most words encountered were not culture-specific, so they were not included in the analysis. Nevertheless, we did find some freetime activities which were cultural per se (e.g., riding a camel) or whose descriptors were clearly pointing at a specific culture. This was the case, for example, of going to the beach (table 2), which may be an activity shared by different cultures yet, it was surrounded in the text by other activities such as: donkey rides and funfair rides which evokes the target culture (Bournemouth).

Regarding international cultures, we observed some glimpses of Asian cultures in Big Surprise (e.g., Manga). Nevertheless, in both textbooks, this category reported a stronger presence of the target culture. To be more specific, we notice a shift from British culture in Big Surprise to a more Americanized perspective in Mission Accomplished. In the same vein, Lappainen (2011) and Su (2014) argued that textbooks are infused with an Americanized view of the target culture. In her analysis of twelve EFL textbooks used at Secondary Education, Cifone Ponte (2019) found a tendency to include American hobbies (e.g., Cheerleading). Nevertheless, this statement cannot be fully extrapolated to our study as our sample reported different results concerning the target culture. We believe this difference can be attributed to the authors' views and own 
cultures mirrored by the textbooks' content or even to the type of textbook (i.e., locally, or internationally produced) (Ilieva, 2000).

Surprisingly, with respect to the source and international cultures, both textbooks and categories reported a monocultural perspective. Our data showed that both textbooks overlook international and source cultures regarding the two semantic categories addressed. Our results are consistent with previous research where the presence of the target culture was described as predominant over the rest of cultures (Sercu, Méndez García \& Castro Prieto, 2004; Wu, 2010; Yuen, 2011; Gómez Rodríguez, 2015; Cifone Ponte, 2019; Ayu, 2020). However, our analysis reported the target culture to be ubiquitous in the cultural content of EFL textbooks used in $6^{\text {th }}$ year of primary education. These results might be interpreted on the grounds of the exclusion of the source and international cultures as part of the cultural component of EFL in the curriculum of La Rioja (Decree 24/2014). Textbook designers follow educational policies and curricula to plan the content of their materials and the curriculum of $6^{\text {th }}$ year of primary education in La Rioja does not mention any other culture other than the target.

We now move on to our second research question which seeks to describe the prototypical associations that emerge from the cultural vocabulary input of the EFL materials. Our data confirmed the inclusion of prototypical associations in the cultural vocabulary of the textbooks. Although we expected to find prototypical words regarding the representation of cultural identities, we only found words belonging to the target culture in both categories, as shown in table 1 and 2. Most of these prototypes referred to inner circle countries. However, in terms of prototypes, a distinction could be 
made between both textbooks. British culture prevails in Big Surprise whereas American culture does in Mission Accomplished.

Owing to the nature of representativeness of the two categories selected (i.e., free-time activities and festivities) in the EFL textbooks used in the curriculum of La Rioja, convergences were foreseen. However, the influence of the target language was evidenced in the information collected showing divergences in the expected results. The reason for this premise may lay in the materials' emphasis on the cultural words elicited by the inner circle countries (Chapelle, 2009; Toprak \& Aksoyalp, 2015; Cifone Ponte, 2019). As predicted, prototypical associations were related to cultural words from American, British and Canadian cultures. The prototype theory states that learning vocabulary is easier and faster through the use of the basic level of categorisation (Kleiber, 1995). In our study, the evidence of basic words representing the immigrant learners' cultures was not as significant as those referring to the target culture. Despite basic words being of paramount importance as our cognitive system depends on our cultural experience (Lakoff 1986), this finding may reveal that the inclusion of those basic words belonging to other cultures was done unintentionally and without considering the cultural diversity in the classroom. On the other hand, evidence on the subordinate level was drawn in Big Surprise. This textbook illustrates how a fruitful vocabulary concerning sub-schemas or the subordinate level of categorisation empowers the richness of the meaning of a word in a category (Rosch \& Lloyd, 1978).

When examining possible cultural aspects in the vocabulary input of the EFL materials selected through prototypical associations, little was concluded. From the four main immigrant students' nationalities in La Rioja (Rumanian, Chinese, Moroccan, Colombian, 
Bolivian and Ecuadorian), only Moroccan and some glimpses to Latin American cultures were observed. Each one of the nationalities was represented in one of the categories suggesting that the pervasiveness of the vocabulary input owes to the target culture.

\section{Conclusions and Implications}

Our main aim was to address the almost total lack of evidence on what it means to highlight the cultural aspects of the immigrant learners represented in the vocabulary input of EFL textbooks through prototypical associations. We have accomplished this goal by directly analysing the content of two selected textbooks used in La Rioja, with special attention to the words enunciated in two different semantic categories (festivities and free-time activities) framed in the curriculum as cultural topics in the learners' textbooks.

Our results showcase a monocultural approach in EFL textbooks for young learners when it comes to their vocabulary input. Immigrant cultures are still not integrated to these materials by means of cultural words. Furthermore, despite the increase of multicultural classrooms due to immigration, multicultural perspectives are not approached in EFL materials. Although considering the cultures coexisting in a classroom and personalizing the content of EFL textbooks is virtually impossible, we advocate a wider representation of international cultures in their vocabulary input. The empowerment provided to British and American cultures through prototypical associations only reveals a lack of effort in integrating a multicultural perspective to EFL materials and, subsequently, in EFL instruction. In this respect, our data justifies a major change in the curriculum of La Rioja, where intercultural 
competence seems to be largely limited to celebrations and traditions from the target culture.

Regarding the inclusion of cultural conceptualizations such as sub-schemas or prototypical levels of categorisation as basic and subordinate, we believe they should be considered of great importance in EFL materials designed for young learners. EFL textbook publishers for young learners need to bear in mind their audience and their level of cultural maturity. Including striking different cultural aspects may emphasise differences (King \& Baxter Magolda, 2005)., which, in turn, may create lack of acceptance, disbelief or even rejection towards the new culture (King \& Baxter Magolda, 2005). Moreover, prototypical associations of words based on sub-schemas or subordinate levels are a potential tool to integrate culture within a certain semantic category.

The first major practical contribution of the present research is that it provides an analysis regarding the influence of the target culture in the textbooks selected. In other words, the lack of evidence of the cultural identity of the immigrant learners in the school materials warrants further research. Specifically, further research might consider a wider sample of textbooks since the two analysed materials only correspond to the most frequently used in the region object of study. Broadening the source of school textbooks may result in emphasising the identification of cultural identities, rather than diminishing the outcomes obtained concerning cultural aspects from two textbooks. Furthermore, delving into specific skills such as writing, reading, listening, and exploring different cultural categories could possibly elicit more evidence of cultural features. 


\section{Acknowledgements}

This research has been generously supported by FEDER/ Ministerio de Ciencia, Innovación y Universidades, and Agencia Estatal de Investigación under Grant PGC2018-095260-B-100.

\section{References}

Abdollahzadeh, E., \& Baniasad, S. (2010). Ideologies in the imported English textbooks: EFL learners and teachers' awareness and attitude. Journal of English Language Teaching and Learning, 2(217), 1-17. Aitchison, J. (2003) Words in the mind: An introduction to the mental lexicon. Blackwell.

Alptekin, C. (1993). Target-language culture in EFL materials. ELTJournal, $472), 136-143$.

https://doi.org/10.1093/elt/47.2.136

Ayu, M. (2020). Evaluation cultural content on English textbooks used by EFL students in Indonesia. JET (Journal of English Teaching), 6(3), 183-192.

Ayuntamiento de Logroño. (2018, April). Informe de Situación de la infancia y la adolescencia de Logroño.

http://www.xn--logroo-

0wa.es/wps/wcm/connect/76597d00459ec8039284d6e226f02e55/IN FORME-SITUACI\%C3\%93N.pdf?MOD=AJPERES

Bahrami, N. (2015). Evaluating the representation of cultural elements in an in-use EFL textbook. Advances in Language and Literary Studies, 6(3), 128-137.

https://doi.org/10.7575/aiac.alls.v.6n.3p.128

Böcü, A. B. \& Razi, S. (2016). Evaluation of textbook series 'Life' in terms of cultural components. Journal of language and linguistics studies, 12(2), 221-237.

Byram, M. (1997). Teaching and assessing intercultural communicative competence. Multilingual Matters.

Canga Alonso, A. \& Cifone Ponte, D. (2015). An analysis of cultural vocabulary in ELT textbooks. Odisea, 16, 83-96. https://doi.org/10.25115/odisea.v0i16.298 
Carcedo González, A. (1998). Desarrollo de la competencia léxica en español LE: análisis de cuatro fases de disponibilidad. Pragmalingüística, 5-6, 75- 94.

https://doi.org/10.25267/Pragmalinguistica.1997.i5.04

Chao, T. (2011). The hidden curriculum of cultural content in internationally published EFL textbooks: A closer look at new American inside out. The Journal of Asia TEFL, 8(2), 189-207.

Chapelle, C. A. (2009). A hidden curriculum in language textbooks: Are beginning learners of French at US universities taught about Canada? The Modern Language Journal, 93(2), 139-152. https://doi.org/10.1111/j.1540-4781.2009.00852.x

Cho, K. (2010). Fostering the acquisition of English prepositions by Japanese learners with networks and prototypes. Fostering language teaching efficiency through cognitive linguistics, 17, 259-276.

\section{https://doi.org/10.1515/9783110245837.257}

Cifone Ponte, M. D. (2019). A Quantitative and Qualitative Analysis of Cultural Vocabulary in Second Baccalaureate EFL Textbooks [Unpublished Doctoral dissertation], Universidad de La Rioja. https://dialnet.unirioja.es/servlet/tesis?codigo $=237525$

Clavel-Arroitia, B., \& Fuster-Márquez, M. (2014). The authenticity of real texts in advanced English language textbooks. ELT journal, 68(2), 124-134.

\section{https://doi.org/10.1093/elt/cct060}

Coleman, L., \& Kay, P. (1981). Prototype semantics: The English word lie. Language, 571), 26-44.

\section{https://doi.org/10.1353/lan.1981.0002}

Cordier, F., \& Dubois, D. (1981). Typicalité et représentation cognitive [Typicality and cognitive representation]. Cahiers de Psychologie Cognitive/Current Psychology of Cognition, 1(3), 299-333.

Cortazzi, M. \& Jin, L.X. (1999). Cultural mirrors: Materials and methods in the EFL classroom. In E. Hinkel (Ed.), Culture in Second Language Teaching, (pp.196-219). Cambridge University Press.

Council of Europe. (2001). Common European framework of reference for languages: Learning, teaching, assessment. University of Cambridge. 
Culture Council. (2008, May). Council conclusions of 22 May 2008 on Intercultural Competences. Official Journal of the European Union.

https://eur-

lex.europa.eu/LexUriServ/LexUriServ.do?uri=OJ:C:2008:141:0014: 0016:EN:PDF

Decreto 24/2014 (Decree 24/2014), de 13 de junio, por el que se Establece el Currículo de la Educación Primaria en la Comunidad Autónoma de la Rioja. https://web.larioja.org/normativa?n=1973

Dehbozorgi, M., Amalsaleh, E., \& Kafipour, R. (2014). Exploring cultural content of three prominent EFL textbooks in Iran (A case study of American English Files, Top Notch and Four Corners). Acta Didáctica Napocensia, $7(1), 69-81$.

https://doi.org/10.5861/ijrse.2017.1816

Duan, J. \& Da, H. (2015). Semantics and vocabulary acquisition and teaching. Studies in Literature and Language, 10(6), 67-71.

Dubois, D. (1981). Lexique et représentations préalables dans la compréhension de phrases. In J.F. Le Ny \& W. Kintsch (Eds.), La compréhension du langage, numéro spécial du Bulletin de psychologie, (pp. 601-606). Larousse.

Dubois, D. (1983). Analyse de 22 catégories sémantiques du français: Organisation catégorielle, lexique et représentation. L'Année Psychologique, 83(2), 465-489. https://doi.org/10.3406/psy.1983.28477

Duñabeitia, J. (2017). Emotional diglossia in multilingual classroom environments: A proposal. Psychology and Cognitive Sciences Open Journal, 3(3), 74-78. https://doi.org/10.17140/PCSOJ-3-126

Fillmore, C. J. (1975). An alternative to checklist theories of meaning. Annual Meeting of the Berkeley Linguistics Society, 1, 123-131. https://doi.org/10.3765/bls.v1i0.2315

Geeraerts, D. (1997). Diachronic prototype semantics: A contribution to historical lexicology. Oxford University Press. 
Gómez Rodríguez, L. (2015). The cultural content in EFL textbooks and what teachers need to do about it. PROFILE, 17(2), 167-187. http://doi.org/10.15446/profile.v17n2.44272

Halverson, R. (1985). Culture and vocabulary acquisition: A proposal. Foreign Language Annals, 18(4), 327-332. https://doi.org/10.1111/j.1944-9720.1985.tb01810.x

Harvey, S., Roskvist, A., Corder, D., \& Stacey, K. (2011). An evaluation of the Language and Culture Immersion Experiences (LCIE) for Teachers programmes: Their impact on teachers and their contribution to effective second language learning. Ministry of Education.

http://www.educationcounts.govt.nz/publications/schooling/anevaluation-of-the-language-and-culture-immersion-experiencesfor-teachers-programme

Hernández Muñoz, N. (2005). Hacia una teoría cognitiva integrada de la disponibilidad léxica: El léxico de los estudiantes castellanomanchegos [Doctoral Dissertation], Universidad de Salamanca.

Holliday, A. (2010). Cultural descriptions as political cultural acts: An exploration. Language and Intercultural Communication, 10(3), 259-272.

\section{https://doi.org/10.1080/14708470903348572}

Hoskins, B., \& Sallah, M. (2011). Developing intercultural competence in Europe: The challenges. Language and Intercultural Communication, 11(2), 113-125.

https://doi.org/10.1080/14708477.2011.556739

Ilieva, R. (2000). Exploring culture in texts designed for use in adult ESL classrooms. TESL Canada Journal, 17(2), 15-20. https://doi.org/10.18806/tesl.v17i2.889

Jackendoff, R. (1983). Semantics and cognition (Vol. 8). The MIT press. Ji, L. J., Zhang, Z., \& Nisbett, R. E. (2004). Is it culture or is it language? Examination of language effects in cross-cultural research on categorization. Journal of personality and social psychology, 87(1), 57-65.

https://doi.org/10.1037/0022-3514.87.1.57 
Jo, S., Chik, A. \& Djonov, E. (2019). The construal of English as a global language in Korean textbooks for primary school children. Asian Englishes, 22, 68-84.

https://doi.org/10.1080/13488678.2019.1627636

Kachru, B. (1985). Standards, codification and sociolinguistic realism: The English language in the Outer Circle. In R. Quirk, \& H. Widdowson, English in the World: Teaching and Learning the Language and Literature (pp. 11-16). Cambridge University Press.

King, P. \& Baxter Magolda, M. (2005). A developmental model of intercultural maturity. Journal of College Student Development, 46(6), 571-592.

https://doi.org/ 10.1353/csd.2005.0060

Kirkgöz, Y., \& Agcam, R. (2011). Exploring culture in locally published English textbooks for primary education in Turkey. CEPS Journal, 1(1), 153-167.

Kleiber, G. (1995). La semántica de los prototipos: Categoría y sentido léxico. Visor.

Lakoff, G. (1986). Classifiers as a reflection of mind. Noun classes and categorization, 7, 13-51.

https://doi.org/10.1075/tsl.7.04lak

Lakoff, G. (1987). Women, fire, and dangerous things: What categories reveal about the mind. The University of Chicago Press. https://doi.org/10.7208/chicago/9780226471013.001.0001

Langacker, R. (1987). Foundations of Cognitive Grammar, I. Stanford University Press.

Lappainen, T. (2011). Presentation of the American culture in EFL textbooks: An analysis of the cultural content of Finish EFL textbooks for secondary and upper secondary education [Master's Dissertation]. University of Jyväskylá.

Lee, I. (2009). Situated globalization and racism: An analysis of Korean high school EFL textbooks. Language \& Literacy, 11(1), 1-14. https://doi.org/10.20360/G2F59N

Liddicoat, A., \& Scarino, A. (2013). Intercultural language teaching and learning. Willey-Blackwell.

https://doi.org/10.1002/9781118482070 
Lukusa, S. T. (1996). A semantic prototype of the English word" Responsible" in Tanzanian usage. Utafiti Journal, 3(1).

McKay, S. (2003). Teaching English as an international language: the Chilean context. ELT Journal, 57(2), 139-148. https://doi.org/10.1093/elt/57.2.139

McKay, S. (2004). Western culture and the teaching of English as an international language (EIL). English Language Teaching Forum, 42(2), 10-15.

https://doi.org/10.1080/07908310608668770

Méndez García, M. (2005). International and intercultural issues in English teaching textbooks: The case of Spain. Intercultural Education, 16(1), 57-68.

https://doi.org/10.1080/14636310500061831

Mora Guarín, J., \& Jiménez Catalán, R. M. (2019). Asociaciones prototípicas en la producción y disponibilidad léxica de adolescentes españoles y eslovenos en español y en inglés como lenguas extranjeras. Verba Hispanica, 271), 73-91.

https://doi.org/10.4312/vh.27.1.73-91

Murphy, G. (2002). The big book of concepts. The MIT Press Cambridge. https://doi.org/10.7551/mitpress/1602.001.0001

Nault, D. (2006). Going global: Rethinking culture teaching in ELT contexts. Language, culture and curriculum, 19(3), 314-328. https://doi.org/10.1080/07908310608668770

Nizegorodcew, A. (2011). Understanding culture through a lingua franca. In J. Arabski \& A. Wojtaszek (Eds.) Aspects of Culture in Second Language Acquisition and Foreign Language Learning (pp. 7-20). Springer. https//:doi.org/10.1007/978-3-642-20201-8_2

Norton, B. (2000). Identity and Language Learning: Gender, ethnicity, and educational change. Longman.

Pavlenko, A. (Ed.), (2009) The Bilingual mental lexicon: Interdisciplinary approaches. Multilingual Matters. https://doi.org/10.21832/9781847691262

Risager, K. (1991). Cultural References in European textbooks: An evaluation of recent tendencies. In E. D. Buttjes, \& M. Byram (Eds.), 
Mediating Languages and Cultures (pp. 181-193). Multicultural Matters.

Rosch, E., \& Lloyd, B. B. (1978). Cognition and categorization. John Wiles \& Sons.

Rosch, E., \& Mervis, C. B. (1975). Family resemblances: Studies in the internal structure of categories. Cognitive psychology, 74), 573605. https://doi.org/10.1016/0010-0285(75)90024-9

Rosch, E., Mervis, C. B., Gray, W. D., Johnson, D. M., \& Boyes-Braem, P. (1976). Basic objects in natural categories. Cognitive Psychology, 8(3), 382-439. https://doi.org/10.1016/0010-0285(76)90013-X

Schwarze, C. (1985). Lexique et compréhension textuelle. Universität Konstanz.

Sercu, L., Méndez García, M. D. C., \& Castro Prieto, P. (2004). Culture teaching in foreign language education: EFL teachers in Spain as cultural mediators. Porta Linguarum, 1, 85-102. https://doi.org/10.30827/Digibug.28351

Sharifian, F. (2003). On cultural conceptualisations. Journal of Cognition and Culture, 3(3), 187-207. https://doi.org/10.1163/156853703322336625

Šifrar Kalan, M. (2017). La universalidad de los prototipos semánticos en el léxico disponible de español. Verba Hispánica, 25(1), 147-165. https://doi.org/10.4312/vh.24.1.147-165

$\mathrm{Su}, \mathrm{Y}$. C. (2014). The international status of English for intercultural understanding in Taiwan's high school EFL textbooks. Asia Pacific Journal of Education, 36(3), 390-408. https://doi.org/10.1080/02188791.2014.959469

Suárez-Orozco, M. (2001). Globalization, immigration, and education: The research agenda. Harvard Educational Review, 71(3), 345-366. https://doi.org/10.17763/haer.71.3.7521rl25282t3637

Taylor, J. (1989) Linguistic categorization: Prototypes in linguistic theory. Oxford University Press.

Toprak, T., \& Aksoyalp, Y. (2015). The question of re-presentation in EFL course books: Are learners of English taught about New Zealand? International Journal of Society, Culture \& Language, 3(1), 91-104.

Tversky, A. (1977). Features of similarity. Psychological Review, 84(4), 327. https://doi.org/10.1037/0033-295X.84.4.327 
Immigrant Learners' Cultural Identities in the Vocabulary Input of...

van Vliet, H. (2019). Wat is een festival? Festival Atlas. https://www.festivalatlas.nl/wat-is-een-festival/

Vermeer, A. (2001). Breadth and depth of vocabulary in relation to L1/L2 acquisition and frequency of input. Applied psycholinguistics, $22(2), 217$. https://doi.org/10.1017/S0142716401002041

Wierzbicka, A. (1992). Semantics, culture, and cognition: Universal human concepts in culture-specific configurations. Oxford University Press on Demand.

Wittgenstein, L. (1953). Philosophical investigations. Macmillan.

$\mathrm{Wu}, \mathrm{J}$. (2010). A content analysis of the cultural content in the EFL textbooks. Canadian Social Science, 6(5), 137-144.

Xia, X., \& Georg-Wolf, H. 2010). Basic-level salience in second language vocabulary acquisition. In D.K. Sabine, B. Frank 6 D. R. Antoon. De Gruyter Mouton (Eds), Fostering language teaching efficiency through cognitive linguistics (79-98) https://doi.org/10.1515/9783110245837.79

Xiang, R., \& Yenika-Agbaw, V. (2019). EFL textbooks, culture and power: A critical content analysis of EFL textbooks for ethnic Mongols in China. Journal of multilingual and multicultural development, 42(4), 1-15.

https://www.doi.org/10.1080/01434632.2019.1692024

Yuan, R. (1990). Semantic transferability and prototypicality in Chinese and English: A study of the semantic acquisition of "thin" by Chinese learners of English. (Master's Dissertation, Iowa State University).

Yuen, K. M. (2011). The representation of foreign cultures in English textbooks. ELT journal, 65(4), 458-466. https://www.doi.org/10.1093/elt/ccq089

Yuen, W. G. (2000). Pedagogical implications of Prototype Theory for the writing of English grammar textbooks: The case of proper names. Selected papers on theoretical and applied linguistics, 13, 490-500. http://ejournals.lib.auth.gr/thal/article/view/6643

First version received: April, 2021 Final version accepted: October, 2021 